\title{
A theoretical framework for evolutionary economic geography: industrial dynamics and urban growth as a branching process
}

\author{
Koen Frenken* and Ron A. Boschma*
}

\begin{abstract}
We propose a framework that specifies the process of economic development as an evolutionary branching process of product innovations. Each product innovation provides a growth opportunity for an existing firm or a new firm, and for an existing city or a new city. One can then obtain both firm size and city size distributions as two aggregates resulting from a single evolutionary process. Gains from variety at the firm level (economies of scope) and the urban level (Jacobs externalities) provide the central feedback mechanism in economic development generating strong path dependencies in the spatial concentration of industries and the specialization of cities. Gains from size are also expected, yet these are ultimately bounded by increasing wages. The contribution of our framework lies in providing a microfoundation of economic geography in terms of the interplay between industrial dynamics and urban growth. The framework is sufficiently general to investigate systematically a number of stylized facts in economic geography, while at the same time it is sufficiently flexible to be extended such as to become applicable in more specific micro-contexts. A number of extensions related to the concepts of knowledge spillover and lock-in, are also discussed.
\end{abstract}

Keywords: evolutionary economic geography, urban growth, firm growth, Zipf, branching, innovation

JEL classifications: B25, B52, L11, L25, R0, R1, R12

Date submitted: 16 November 2006 Date accepted: 12 March 2007

\section{Introduction}

By taking an explicit dynamic perspective, Evolutionary Economic Geography complements neoclassical and institutional modes of analysis in economic geography (Boschma and Frenken, 2006). Evolutionary Economic Geography explains the spatial evolution of firms, industries, networks, cities and regions from elementary processes of the entry, growth, exit and (re-)location of firms. What renders evolutionary theory attractive, albeit in economic geography or in the social sciences more generally, is that it provides a general theory of change while being applicable empirically to specific processes in space and time. This makes evolutionary theory compatible with a

*Section of Economic Geography, Urban and Regional research centre Utrecht (URU), Faculty of Geosciences, Utrecht University, The Netherlands.

email<K.Frenken@geo.uu.nl> 
contextual view as advocated in economic geography, without giving up the ideal of developing a theoretical framework that goes beyond the specific and the unique.

There is an increasing number of studies in economic geography that take an evolutionary perspective (for general discussions, see Boschma and Frenken, 2006; Martin and Sunley, 2006; Frenken, 2007). These studies, however, remain rather fragmented, and it is often not made explicit what is evolutionary about these studies (see also Essletzbichler and Rigby this issue). The main reason for the current state of affairs is that a fully articulated Evolutionary Economic Geography has not yet been developed. In this article, it is certainly not our goal to end up with such a shortlist of features that should be part and parcel of any evolutionary approach in economic geography. It is still too early for that, and maybe it is just an outdated idea to think theory could be reduced to a few fundamentals in one basic model. Nevertheless, the aim of the article is to make a step forward in this respect. ${ }^{1}$

Basically, economic geography deals with the uneven distribution of economic activity across space. An evolutionary approach centres on historical processes that have produced these patterns. Characteristic for any evolutionary theory is that it explains a current state of affairs from history: 'the explanation to why something exists intimately rests on how it became what it is' (Dosi, 1997, 1531). It means that economic geography is inseparable from economic growth processes, because spatial patterns emerge from processes that have taken place in the past. At the same time, spatial distributions affect subsequent patterns of growth due to the uneven spatial distribution of resources built up in the past. Time and space are thus intrinsically linked in an evolutionary framework.

To understand the uneven distribution of economic activity across space as the outcome of historical processes, stochastic growth models are of particular use as these models account for path dependence in which each event changes the probability of a next event to occur (Simon, 1955; David, 1985; Arthur, 1989). ${ }^{2}$ Stochastic models of urban growth have a long intellectual history (Simon, 1955; Robson, 1973; Arthur, 1987; Krugman, 1996; Batty, 2005; Pumain, 2006). A shortcoming of urban growth models is that they take spatial entities as the unit of analysis. The firm, or the division within a firm, as an entity is less problematic, because firms are the agents of change (Boschma, 2004). Taking product divisions as the unit of analysis, we propose a theoretical framework that defines growth as stemming from product innovations leading to new product divisions within an existing firm or a new firm, and within an existing city or a new city. This perspective allows us to derive both the firm size distribution and the city size distribution from a single elementary growth process $a$ la Simon (1955). It also allows us to specify economic growth as an evolutionary process where the scope for innovation is dependent on the existing variety within firms and within cities. And, by distinguishing between incremental innovation (within a productgroup) and radical innovation (creating a new product group), growth can be

1 Other approaches in evolutionary economic geography include a regional 'Darwinian' approach (Rigby and Essletzbichler, 1997; Essletzbichler and Rigby, 2005; see also Hodgson and Knudsen, 2006) and a theory-of-the-firm approach to explain the existence and evolution of clusters (Maskell, 2001; Iammarino and McCann, 2006; Stam, 2007; Maskell and Malmberg, this issue).

2 Even if the New Economic Geography sometimes claims to deal with path dependent processes, the way in which time is conceptualized is different, because it is grounded in equilibrium analysis in which ‘dynamics' only enter via parameter changes (Martin, 1999; Boschma and Frenken, 2006). 
decomposed into different stages of industry lifecycles, each of which has a distinctive spatial evolution (Klepper, 2002a; Boschma and Wenting, 2007).

We will proceed as follows. In Section 2, we introduce the product division as the unit of analyses and the concept of routines as the main theoretical concept. In Section 3, we reformulate Simon's original model of stochastic growth as a branching process of routines stemming from product innovations leading to new product divisions. In Section 4, we elaborate on the evolutionary branching dynamics by introducing the distinction between incremental and radical innovation and show how new industries can emerge from existing industries. Section 5 elaborates the model to include positive feedbacks stemming from variety and negative feedbacks stemming from high wages. We then turn in Section 6 to possible extensions of the framework to include the concepts of social networks, knowledge spillovers and lock-in. Section 7 concludes.

\section{Routines}

Evolutionary economists start from the premise that firms rely on organizational routines in their productive and decision-making processes. Routines are built up over time and are, to a large extent, idiosyncratic to the firm. Markets operate as selection mechanisms upon the heterogeneity of routines among firms resulting in systematic differences in the growth rates of firms (Nelson and Winter, 1982). Organizational routines, as for individual routines, consist of a large part of experience knowledge and tacit knowledge. Both aspects of organizational routines render them difficult to imitate by other firms. They are competencies to the firm that largely determine the competitiveness of a firm (Teece et al., 1997). If one accepts the premise of organizations consisting of routines, one can accept an Evolutionary Economic Geography that describes economic development by changes in the time-space distribution of routines (Boschma and Frenken, 2003, 2006). This means that the firm rather than the locality is the unit of analysis. The shift from territory to firm resonates a more general reorientation in economic geography from territorial analysis of endowments or institutions to firm analysis of routines and competencies and their embeddedness in the local and global economy (Maskell, 2001; Boschma, 2004; Wrigley et al., 2005).

The evolutionary theory of the firm views firm growth as a progressive process of diversification. As the turnover of a single product is ultimately bounded by the minimum efficient scale and consumer demand for a specific product, further growth requires a firm to diversify in other products (Penrose, 1959). Diversified firms can be characterized by firm routines that apply to all products in the firm and product-specific routines that are used in the production of a particular product. Yet, the productspecific routines are closely related because firms typically diversify into products that are technologically related to its current products. One can thus think of diversification as a branching process in which new routines associated with a product innovation are generated by recombining and modifying existing routines.

The time-space distribution of routines in the economy is dependent on the processes of routine replication. One can distinguish between three different processes of routine replication. First, routines are replicated within the firm especially in the process of setting up new divisions or subsidiaries (Kogut and Zander, 1993; Winter and Szulanski, 2001). Second, spin-off firms inherit part of the routines from existing firms as evidenced by the correlation of the performance of parent firms and their spin-offs 
(Klepper, 2001; Klepper and Sleeper, 2005). Third, routines are replicated through labour mobility. Employees bring with them ways of doing things that they sometimes attempt to implement in the new organization (Almeida and Kogut, 1999; Breschi and Lissoni, 2001; Agrawal et al., 2006; Cantner and Graf, 2006). For all the three forms of routine replication, it holds that the replication process is generally partial (not all routines are necessarily transferred) and imperfect (routines are not necessarily copied in an exact manner).

The spatial dimension of routine replication lies in the locational dynamics of the replication process. For each process of routine replication, replication can take place locally or over distance. Generally, routine replication occurs locally. Most spinoffs locate near their parent firm (Egeln et al., 2004), most new divisions are created inside existing plants and most employees change jobs within the same labour market area. This means that the lineage structure between routines is spatially structured: once certain routines (casu quo industries) become dominant in certain regions, subsequent evolution of these routines is expected to occur primarily in the same region (Rigby and Essletzbichler, 1997; Essletzbichler and Rigby, 2005; Boschma and Wenting, 2007).

In the following, we incorporate the replication process of routines by multidivisional firms, spinoffs and mobile employees in a simple framework. The basic model that we propose reformulates Simon's (1955) seminal model in a way that we can understand both firm growth and urban growth as the outcome of a single stochastic growth process.

\section{The basic framework}

In geography, stochastic growth models are being used as a methodology to explain city size distributions. City size distributions are well approximated by Zipf's law, which states that the size of the $n$-th ranked city is $1 / n$ times the size of the largest city (Zipf, 1949). To understand this distribution as the result of a historical growth process, Simon (1955) modelled city growth by discrete increments (lumps). The probability that a city receives this lump is proportional to its size and with some small probability the lump can create a new city. Having the latter probability approach to zero, the resulting distribution will be Zipf distributed.

The nihilistic nature of the model rendered Simon's approach disputed. For example, Simon's model has been criticized because it regards cities as collections of lumps without any reference to interdependencies between cities (Hohenberg and Lees, 1995; Pumain, 2006). Zipf's law as an empirical regularity has also been questioned (Pumain and Moriconi-Ebrard, 1997; Overman and Ioaniddes, 2001; Gabaix and Ioannides, 2004; Pumain, 2006). Still, we consider Simon's model as a useful analytical starting point in evolutionary economic geography for two reasons. First, the model performs remarkably well empirically and is extendable as to account for more specific empirical outcomes. Second, the model is, in essence, an evolutionary model in that the probability of a particular event to occur is affected by the events that have taken place in the past (path dependence).

In an evolutionary perspective, however, a particular feature of Simon's model remains problematic. The model lacks micro-foundations as urban growth is modelled as stemming from exogenous lumps rather than from agents' decisions. From an evolutionary perspective, reasoning from spatial units makes it difficult to introduce 
explicit firm dynamics into a theoretical framework (Boschma, 2004). Yet, firm dynamics ultimately drive economic growth through the diffusion of routines in the economic system. An evolutionary approach to economic geography can thus build on a demographic perspective, which focusses on changing spatial patterns resulting from entry, growth and exit of firms. ${ }^{3}$

Reasoning from firms, we take product divisions as the unit of analysis, where each division belongs to a particular firm and is located in a particular city. One can then derive the firm size distribution by aggregating product divisions into firms and the city size distribution by aggregating product divisions into cities. In this framework, firm growth and urban growth occur simultaneously through the establishment of new product divisions. In terms of Simon's model, the lumps that drive growth can be considered as product innovations exploited by entrepreneurs that establish a new product division. ${ }^{4}$ This perspective is in line with the Penrosian theory of the firm that views firm growth as a process of progressive product diversification (Penrose, 1959; Sutton, 1997; Bottazzi and Secchi, 2006). By reformulating Simon's stochastic model as a growth process fuelled by new product divisions, and by assigning each new product division simultaneously to a firm and a city, the firm size distribution and the city size distribution can be derived from one single growth process. Note that in this perspective, growth by definition involves an increase in product variety in the economy, an assumption that gained acceptance in new growth theory (Romer, 1990; Weitzman, 1998) and evolutionary growth theory (Pasinetti, 1993; Saviotti and Pyka, 2004). ${ }^{5}$

Considering Simon's lumps as product innovations, we assume that all product innovations originate from an employee working in a firm. Assuming that each employee has an equal probability to develop a product innovation, the probability that someone in a firm develops a product innovation is proportional to the size of the firm, as in Simon's original model. In case an employee develops a product innovation and starts a new product division, we can distinguish between three probabilities, which we call organizational parameters. With probability $p$ the employee will commercialize the innovation in-house leading to a new product division within the parent firm. With probability $p *$ the employee will commercialize the product innovation in another firm by changing jobs, where we assume that the probability that an employee chooses a particular firm is proportional to its size. ${ }^{6}$ The remaining probability $\left(1-p-p^{*}\right)$ is the probability that the employee creates a spinoff firm.

Empirically, we expect that most innovations are implemented within the organization itself through the establishment of a new product division, because the employee faces high costs in moving to a different firm with different firm routines or in setting

3 Examples of studies combining firm demography and economic geography are Hannan et al. (1995), Klepper (2002a), Stuart and Sorenson (2003), Bottazzi et al. (2004, 2007), Brenner (2004, 2005), Maggioni (2002, 2006), Van Wissen (2004), Buenstorf (2006) and Boschma and Wenting (2007).

4 This means that we do not consider growth resulting from an increase in turnover in existing products or through mergers. However, the framework does not prohibit such extensions.

5 Our argument mirrors some aspects of the work by Allen (1997), where urban growth occurs through the emergence of new sectors, though his work was framed in a Christallerian setting.

6 This assumption is equivalent to random interaction models of the gravitational type, which state that migration flows between entities are proportional to their size (Pumain 2006, 202). This assumption can be relaxed to include geographical proximity as a determinant of these flows as in the original gravity model. Other forms of proximity may also be relevant (Boschma, 2005). For example, one expects most inventors to move to firms within the same industry (Breschi and Lissoni, 2006). 
Table 1. Possible events resulting from a product innovation

\begin{tabular}{ll}
\hline$(p)(q)$ & Internal firm growth in city of origin \\
$(p)\left(q^{*}\right)$ & Internal firm growth in another city \\
$(p)\left(1-q-q^{*}\right)$ & Internal firm growth in a new city \\
$\left(p^{*}\right)(q)$ & Firm growth though labour mobility in city of origin \\
$\left(p^{*}\right)\left(q^{*}\right)$ & Firm growth though labour mobility in another city \\
$\left(p^{*}\right)\left(1-q-q^{*}\right)$ & Firm growth though labour mobility in a new city \\
$\left(1-p-p^{*}\right)(q)$ & Spinoff in city of origin \\
$\left(1-p-p^{*}\right)\left(q^{*}\right)$ & Spinoff in another city \\
$\left(1-p-p^{*}\right)\left(1-q-q^{*}\right)$ & Spinoff in a new city \\
\hline
\end{tabular}

up an own risky venture (Nelson and Winter, 1982; Winter and Szulanski, 2001). Thus, we get $p \gg p^{*}$ and $p \gg 1-p-p^{*}$. This corresponds to Simon's original model, where the probability of creating a new entity, here $1-p-p^{*}$, should be close to zero to obtain a size distribution that fits well with the skewed Zipf distribution (if instead $1-p-p^{*}$ is close to one, we would obtain a uniform distribution where most firms produce one product).

In a similar fashion, we can specify the locational behaviour of firms. Again, three probabilities can be distinguished which we call locational parameters. With probability $q$ the innovation will be commercialized in the city of origin. With probability $q^{*}$ the innovation will be commercialized in another city where the probability that a particular city attracts the product innovation is proportional to its size. ${ }^{7}$ And with the remaining probability $1-q-q^{*}$ the innovation will be commercialized in a new city.

Empirically, we expect that most innovations are commercialized within the parent city because of high relocation costs faced by the employee and the territorial embeddedness of the routines within the wider urban framework of firms and institutions (Gertler, 1995; Wrigley et al., 2005). Routines that are successful in one location are not necessarily successful in another location as a mismatch may occur between firms' routines and the local institutional context. Thus, we get $q \gg q^{*}$ and $q \gg 1-q-q^{*}$.

Taken together, this reformulation of Simon's model incorporates nine possible events resulting from a product innovation (Table 1). As such, the framework provides a rich repertoire for formal modelling approaches with only four parameters $\left(p, p^{*}, q\right.$ and $\left.q^{*}\right)$. Firms and cities being the aggregates of product divisions, the model will produce the Zipf law for both the firm size distribution and the city size distributions in a single model. Below, we will elaborate on the framework to include more specific evolutionary dynamics driven by a branching process of related product innovations and a selection environment based on product competition.

7 Again, this assumption is equivalent to random interaction models of the gravitational type, which state that migration flows between entities are proportional to their size (Pumain, 2006). This assumption can again be relaxed to include other determinants of these flows, such as geographical and other forms of proximity (Boschma, 2005). For example, one expects most inventors to move to cities within the same region (Breschi and Lissoni, 2006). 


\section{Innovation, competition and inheritance}

Our model of firm growth and urban growth is conceptually consistent with new growth theory (Romer, 1990; Weitzman, 1998) and evolutionary growth theory (Pasinetti, 1993; Saviotti and Pyka, 2004), which consider the process of economic growth as one involving increasing product variety. Our contribution in this respect is to integrate the urban growth process with the underlying industrial dynamics by assuming that each new product also leads to the creation of a new organizational entity. This coupling allows us to introduce a lineage structure among organizational entities, which represents the transmission paths of firm routines between the parent firm and the employee responsible for bringing the new product to the market in a new organizational entity. The resulting branching process is such that the number of product divisions will be equal to the number of product varieties. Consequently, competition between organizational units in this model is of the monopolistic competition type, since each product is different and imperfectly substitutable. ${ }^{8}$

Despite the transmission of firm routines from the parent firm to the new organizational entity, the latter is unique in its set of routines, because it will develop product-specific routines. The product-specific routines associated with the new product will often be related to other product-specific routines present in the parent firm. As the employee formerly worked in another product division, it is likely that most product innovations are incremental in that an existing product is changed in a minor way. This explains why multi-product firms are generally specialized in the same product group (Nelson and Winter, 1982; Montgomery, 1994).

Because related products in the same product group are close substitutes and demand will eventually saturate, growth opportunities for a firm that is specialized in a single product group will become depleted. The distinction between incremental and radical innovation, then, is important as radical innovations are necessary to prevent the pool of incremental innovations from depletion. A radical innovation is defined here as a product innovation that does not lead to a related product within an existing product group, but opens up a new product group providing a pool of future opportunities for future product innovations. Thus, radicalness in our framework is defined in terms of demand. A radical innovation leads to a new product group defined, where products within this product group are not substitutable with products in other product groups. ${ }^{9}$ The new product group defines a new industry that will attract new entries in search for new production opportunities. After each radical innovation, a new industry lifecycle starts off with its distinctive spatial evolutionary pattern (Boschma and Lambooy, 1999; Klepper, 2002a; Boschma and Wenting, 2007).

Once we introduce the distinction between incremental and radical innovation in this way, firm growth is no longer strictly proportional to size as in Simon's model. Rather, growth becomes dependent on the product competition between its products and

8 Note in this respect the commonalities of our approach with the spinoff model of Klepper and Sleeper (2005) and the urban growth model proposed by Duranton (2006).

9 In our definition, radicalness does not necessarily refer to descent. In our view, most radical innovations descend from the knowledge and routines of the parent firm in the same way as incremental innovations do. Only some radical innovations may result in a sharp break with the past, and may even be 'competence destroying' with regard to existing routines (Anderson and Tushman, 1990). 
competing products (Saviotti and Pyka, 2004; Klepper and Sleeper, 2005). This means that we introduce a selection environment that operates at the level of products, where selection pressure is increasing with the number of competing products within the same product group. ${ }^{10}$ As the product space becomes more crowded over time, the probability of product innovation will fall. ${ }^{11}$ Firms entering early on in a new industry thus face better growth opportunities than firms entering later. Similarly, cities hosting new industries will experience higher growth for a sustained period of time than other cities. In empirical research, such instances of path dependence in firm growth and urban growth have indeed been observed as evidenced by temporal autocorrelation in growth rates (Bottazzi et al., 2002; Bottazzi and Secchi, 2006; Pumain, 2006). However, whether these periods of sustained growth can indeed be attributed to series of innovations clustered in space and time requires more empirical research.

\section{Positive and negative feedbacks}

The basic model is essentially a model of exogenous growth, since the probability of innovation is purely stochastic and independent of any economic variable. However, an evolutionary perspective suggests that growth is self-feeding because the probability of innovation increases with the variety available for recombination, a process termed 'recombinant growth' (Weitzman, 1998). This principle of endogenous growth holds equally for firms and cities: the more product varieties already present in a firm or city, the higher the probability new product varieties can be generated through recombination of old routines. This feedback relationship is non-linear in that the potential for new ideas rises more than proportional with the stock of existing ideas. Thus, even though the process of growth increases the potential product variety in firms and in cities, firms and cities are expected to be specialized in varieties that fall under a small set of product groups.

In our framework, the feedback mechanism stemming from variety operates simultaneously at two levels as shown in Figure 1. At the firm level, more diversified firms also have a larger scope for innovation. This means that the probability of an innovation to occur increases with the degree of diversification (Bottazzi and Secchi, 2006). Similarly at the urban level, more diversified cities have a higher chance of generating a new innovation than less diversified cities. This phenomenon is better known as Jacobs externalities (Jacobs, 1969). Note that a second type of advantage stemming from variety is the traditional portfolio effect: firms and cities with a more varied product portfolio will be less vulnerable to external shocks (Montgomery, 1994; Frenken et al., 2007).

As depicted in Figure 1, a second feedback mechanism operates through scale economies in doing R\&D both at the firm level and the urban level (urbanization externalities). Here, we find a parallel with older literature that associates firm size with innovativeness (Schumpeter, 1942) and city size with innovativeness (Hagerstrand, 1967). Empirical evidence on firm size and innovation (Cohen and Klepper, 1996) and

10 A further specification of product competition could make use of Klepper and Sleeper (2005) to model the exact location of product entries in a Hotelling space.

11 This also explains why the entry rate is inversely proportional to the age of the industry (Carroll and Hannan, 2000; Klepper and Sleeper, 2005). 


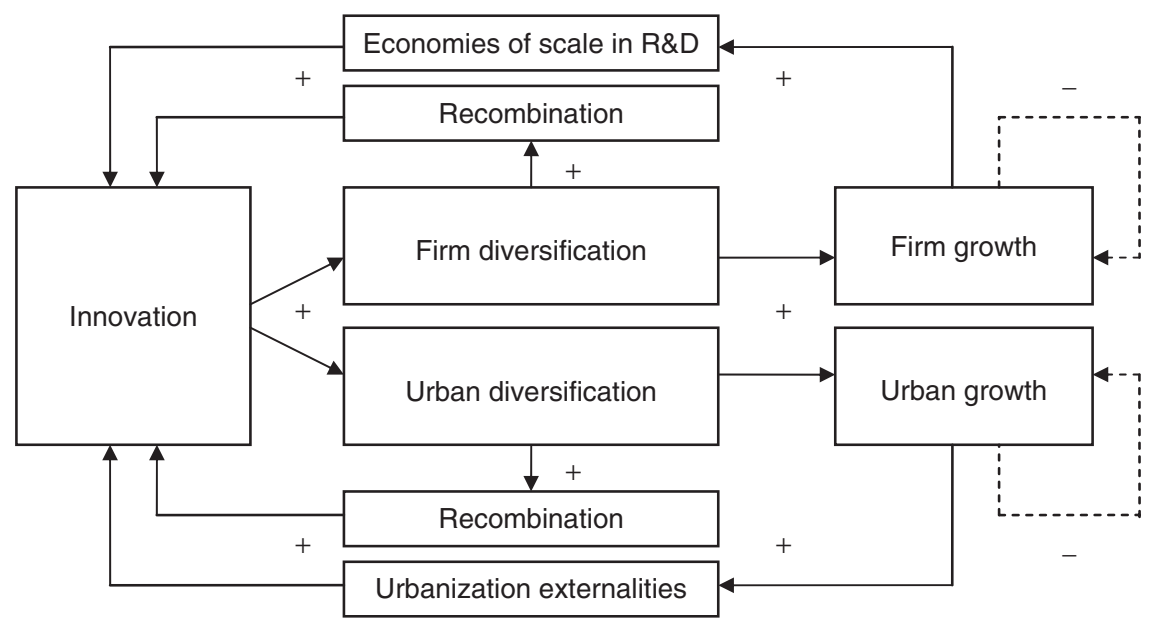

Figure 1. A schematic representation of the analytical framework.

city size and innovation (Bettencourt et al., 2007) indeed supports these relationships. Yet, the observed correlation between size and innovation may solely be due to the correlation between diversification and size. It remains to be seen whether size truly has a separate effect on innovation, which is an empirical question.

Negative feedback cycles are assumed to operate on size only as indicated by the dashed lines in Figure 1. Wages tend to rise with firm size and city size to an extent that is not compensated for by higher productivity (Brown and Medoff, 1989; Axtell and Florida, 2006). This stylized fact suggests that growth in itself is subject to decreasing returns. In our framework, this means that firms and cities will shrink in the absence of product innovation: mature product divisions with low value-added are sold by larger firms (firm divestment) creating small firms with lower wages or are moved to smaller cities with lower wages (firm relocation). This process replicates the product lifecycle logic operating between high-wage and low-wage cities as well as between high-wage and low-wage countries. ${ }^{12}$ One can thus think of a spatial division-of-labour logic in which large firms and large cities grow mainly through the production of new products and smaller firms and smaller cities through production of mature products. ${ }^{13}$

12 A recent study by Pumain et al. (2006) provides systematic evidence for this thesis showing that mature industries are overrepresented in smaller cities while emerging industries are overrepresented in larger cities. As expected, basic services are equally represented in larger and smaller cities.

13 Though the framework represented by Figure 1 specifies an endogenous growth process based on the evolutionary principle of recombination, innovation opportunities are also exogenously determined by macro-innovations that open up many new branches. Such inventions have been associated with long waves in the economy (Freeman and Perez, 1988). It follows that historical periods with many radical innovations ('first industrial revolution', 'second industrial revolution' and 'third industrial revolution') generate processes of rapid growth of firms and cities, while periods in between with few radical innovations are characterized by divestment and suburbanization (Van den Berg, 1987; Hall and Preston, 1988; Pumain, 2006). Furthermore, since such inventions are not endogenously generated in firms by recombination, but rather are 'competence destroying' regarding existing routines, one can expect that small firms and small cities are more capable of exploiting these opportunities than large firms and large cities. In the scheme, this would provide another negative feedback operating on larger firms and larger cities. 


\section{Extensions}

We envisage at least two extensions of the basic framework. First, the concept of knowledge spillovers can be incorporated in our framework by assuming that knowledge spillovers occur in social networks (Almeida and Kogut, 1999; Breschi and Lissoni, 2001; Maggioni and Uberti, 2005). This implies that the amount of knowledge spillovers a firm receives depends on the social networks of the employees working in the product divisions belonging to the firm. And, similarly, the amount of knowledge spillovers a city receives depends on the social networks of its employees within the product divisions located in the city. One can specify the effect of such spillovers by assuming that each time an employee within a product division develops a product innovation, it raises the probability that the employees who are part of the employee's social network, develop a product innovation in the next time step(s).

Following Breschi and Lissoni (2003, 2006), one can construct social networks between inventors from the labour mobility flows, where two inventors have a social link if they have ever worked together in the same firm. The social distance between any two inventors can then be defined as the shortest path between two inventors in the network. Breschi and Lissoni (2003, 2006) showed that knowledge spillovers, as measured by patent citations, are highly correlated with social distance. Our framework thus naturally extends to recent methodologies using social network analysis. In our framework, however, one would assign a social link between two inventors if they work or have worked together for the product division rather than the same firm, because our unit of analysis is the product division.

A second extension of the model is to change the organizational and locational parameters in the framework into decision variables of firms. In particular, one expects organizational and locational decisions to be dependent on the nature of the innovation. As innovations can be considered as being more or less radical, the radicalness of innovation will impact the organizational form and locational behaviour of firms. Regarding the organizational forms, one can expect that the probability that an innovation leads to internal firm growth decreases with radicalness. To exploit the firm routines built up in the past, firms tend to prefer incremental over radical innovations since firm routines that fitted in one industry may not be suitable in another industry (Anderson and Tushman, 1990). Radical innovations, therefore, are more likely to lead to labour mobility or the creation of a spinoff firm than incremental innovations. Regarding locational decisions, the more radical an innovation, the less likely it will benefit from existing routines and institutions within the parent city. For that reason, radical innovations are more likely to be commercialized in a location different from the location it is conceived, compared to less radical innovations. ${ }^{14}$ This also provides an explanation why firms and cities can experience a negative lock-in: the inability to incorporate radical innovations leads firms and cities to accept only incremental innovations, the scope for which get depleted by saturing market demand (Anderson and Tushman, 1990; Grabher, 1993; Hassink, 2005; Wezel and Van Witteloostuijn, 2006).

14 Put differently, the openness of the Windows of Locational Opportunity increases with radicalness of the innovation in question (Storper and Walker, 1989; Boschma and Lambooy, 1999). 
This type of reasoning can be further elaborated in a multi-level logic in which organizational and locational parameters can be made specific not only to firms and cities, but also to industries and territories. For example, we know that industries differ in their technological regimes of innovation and competition (Malerba and Orsenigo, 1996; Breschi and Malerba, 1997; Breschi, 2000). Organizational and locational variables are thus expected to be - to some extent - industry-specific. And, a territorial specification is possible in our framework as the organisational and locational variables can be made specific to regions or countries. For instance, the territorial institutional framework is likely to affect the organizational and locational variables (Cooke et al., 1998; Hall and Soskice, 2001).

\section{Conclusion}

Our framework specifies the process of economic development as an evolutionary branching process of product innovations. The contribution of our framework lies in providing a micro-foundation of economic geography in terms of the interplay between industrial dynamics and urban growth. Each product innovation provides a growth opportunity for an existing firm or a new firm, and for an existing locality or a new locality. One can then obtain both firm size and city size distributions as two aggregates resulting from a single evolutionary process. Gains from variety at the firm level (economies of scope) and the urban level (Jacobs externalities) provide the central feedback mechanism in economic development generating strong path dependencies in the spatial concentration of industries and the specialization of cities. Gains from size are also expected, yet these are ultimately bounded by increasing wages.

Being a simple framework based on stochastic growth of firms and cities, the framework can be extended in many directions. Our framework is sufficiently general to investigate systematically a number of stylized facts in economic geography, while at the same time it is sufficiently flexible to be extended such as to become applicable in more specific micro-contexts. A number of such extensions have been discussed.

Our framework has a number of limitations. First, our model views growth as an evolutionary process of branching through product innovation abstracting from productivity differences between firms and between cities (Baldwin and Okubo, 2006). A second limitation of the framework is that we reason from product divisions abstracting from functional divisions that support product divisions including headquarters, R\&D departments and marketing departments. We thus have implicitly assumed that the spatial distribution of functional divisions follows from product divisions, which is unlikely to be the case, because functional divisions are overrepresented in large cities (Castells, 1996; Pumain et al., 2006). Third, we abstracted from corporate mergers affecting the firm size distribution and from mergers between cities affecting the city size distribution. A final limitation of the framework is that the demand side of the economy is reduced to a given preference distribution in a Hotelling space.

In all, our framework is consistent with Simon's model of stochastic growth as well as with some of the recent models proposed in the fields of endogenous and evolutionary growth theory. What is more, we have integrated a theory of urban growth with explicit industrial dynamics. The next step is to develop formal models to derive statistical properties including firm size distributions, city size distributions, 
diversification patterns at the firm and urban levels and the temporal and spatial autocorrelations in growth rates. Second, the theoretically derived results should be tested systematically and for different data sets. This can be done using firm size and city size distributions and the changes herein over time, as well as more detailed data for specific industries and for specific territories. We hope that the possible extensions and current limitations, as mentioned, will spur further research of the basic framework in order to provide a stronger theoretical and empirical basis for Evolutionary Economic Geography.

\section{References}

Agrawal, A., Cockburn, I., McHale, J. (2006) Gone but not forgotten: knowledge flows, labor mobility, and enduring social relationships, Journal of Economic Geography, 6: 571-591.

Allen, P. M. (1997) Cities and Regions as Self-Organizing Systems: Models of Complexity. London: Gordon and Breach.

Almeida, P. and Kogut, B. (1999) Localisation of knowledge and the mobility of engineers in regional networks, Management Science, 45: 905-917.

Anderson, P. and Tushman, M. L. (1990) Technological discontinuities and dominant designs: a cyclical model of technological change, Administrative Science Quarterly, 35: 604-633.

Arthur, W. B. (1987) Urban systems and historical path dependence. In J. H. Ausubel and R. Herman (eds) Cities and their Vital Systems, pp. 85-97. Washington DC: National Academy Press.

Arthur, W. B. (1989) Competing technologies, increasing returns, and lock-in by historical events, The Economic Journal, 99: 116-131.

Axtell, R. and Florida, R. (2006) Emergent cities: a microeconomic explanation for Zipf's Law, Manuscript.

Baldwin, R. E. and Okubo, T. (2006) Heterogeneous firms, agglomeration and economic geography: spatial selection and sorting, Journal of Economic Geography, 6: 323-346.

Batty, M. (2005) Cities and Complexity. Understanding Cities with Cellular Automata, Agent-Based Models, and Fractals. Harvard MA: MIT Press.

Bettencourt, L. M. A., Lobo, J., Strumsky, D. (2007) Invention in the city: increasing returns to patenting as a scaling function of metropolitan size, Research Policy, 36: 107-120.

Boschma, R. A. (2004) The competitiveness of regions from an evolutionary perspective, Regional Studies, 38: 1001-1014.

Boschma, R. A. (2005) Proximity and innovation. A critical assessment, Regional Studies, 39: 61-74.

Boschma, R. A. and Frenken, K. (2003) Evolutionary economics and industry location, Review for Regional Research, 23: 183-200.

Boschma, R. A. and Frenken, K. (2006) Why is economic geography not an evolutionary science? Towards an evolutionary economic geography, Journal of Economic Geography, 6: 273-302.

Boschma, R. A. and Lambooy, J. G. (1999) Evolutionary economics and economic geography, Journal of Evolutionary Economics, 9: 411-429.

Boschma, R. A. and Wenting, R. (2007) The spatial evolution of the British automobile industry. Does location matter? Industrial and Corporate Change, in press.

Bottazzi, G., Cefis, E., Dosi, G. (2002) Corporate growth and industrial structures: some evidence from the Italian manufacturing industry, Industrial and Corporate Change, 11: 705-723.

Bottazzi, G., Dosi, G., Fagiolo, G., Secchi, A. (2004, 2007) Sectoral and geographical specificities in the spatial structure of economic activities. LEM Working Paper 2004-21, http://www.lem. sssup.it/

Bottazzi, G., Dosi, G., Fagiolo, G., Secchi, A. (2007) Modelling industrial evolution in geographical space, Journal of Economic Geography, 7: 651-;672.

Bottazzi, G. and Secchi, S. (2006) Gibrat's Law and diversification, Industrial and Corporate Change, 15: 847-875. 
Brenner, T. (2004) Local Industrial Clusters. Existence, Emergence and Evolution. London/ New York: Routledge.

Brenner, T. (2005) A stochastic theory of geographic concentration and the empirical evidence in Germany. Papers on Economics and Evolution 05.23, Max Planck Institute of Economics, Jena, http://www.econ.mpg.de/.

Breschi, S. (2000) The geography of innovation: a cross-sector analysis, Regional Studies, 34: 213-230.

Breschi, S. and Lissoni, F. (2001) Localised knowledge spillovers vs. innovative milieux: knowledge "tacitness" reconsidered, Papers in Regional Science, 80: 255-273.

Breschi, S. and Lissoni, F. (2003) Mobility and social networks: localised knowledge spillovers revisited. CESPRI Working Paper 142, http://www.cespri.unibocconi.it/ (forthcoming in the Annales d'Economie et de Statistique).

Breschi, S. and Lissoni, F. (2006) Mobility of inventors and the geography of knowledge spillovers. New evidence on US data. CESPRI Working Paper 184, http://www.cespri. unibocconi.it/

Breschi, S. and Malerba, F. (1997) Sectoral innovation systems: technological regimes, Schumpeterian dynamics, and spatial boundaries. In C. Edquist (ed.) Systems of Innovation. Technologies, Institutions and Organizations, pp. 130-156. London/Washington: Pinter.

Brown, C. and Medoff, J. L. (1989) The employer size-wage effect, Journal of Political Economy, 97: 1029-1057.

Buenstorf, G. (2006) How useful is generalized Darwinism as a framework to study competition and industrial evolution? Journal of Evolutionary Economics, 16: 511-527.

Carroll, G. R. and Hannan, M. T. (2000) The Demography of Corporations and Industries. Princeton, NJ: Princeton University Press.

Cantner, U. and Graf, H. (2006) The network of innovators in Jena: an application of social network analysis, Research Policy, 35: 463-480.

Castells, M. (1996) The Rise of the Network Society. Oxford: Blackwell.

Cohen, W. M. and Klepper, S. (1996) A reprise of size and R \& D, The Economic Journal, 106: 925-951.

Cooke, P., Uranga, M. G., Extebarria, G. (1998) Regional innovation systems: an evolutionary perspective, Environment and Planning A, 30: 1563-1584.

David, P. A. (1985) The economics of QWERTY, American Economic Review (Papers and Proceedings), 75: 332-337.

Dosi, G. (1997) Opportunities, incentives and the collective patterns of technological change, The Economic Journal, 107: 1530-1547.

Duranton, G. (2006) Some foundations for Zipf's law: product proliferation and local spillovers, Regional Science and Urban Economics, 36: 542-563.

Egeln, J., Gottschalk, S., Rammer, C. (2004) Location decisions of spin-offs from public research institutions, Industry and Innovation, 11: 207-223.

Essletzbichler, J. and Rigby, D. L. (2005) Competition, variety and the geography of technology evolution, Tijdschrift voor Economische en Sociale Geografie, 96: 48-62.

Essletzbichler, J. and Rigby, D. L. (2007) Exploring evolutionary economic geographies, Journal of Economic Geography, 7: 549-571.

Freeman, C. and Perez, C. (1988) Structural crisis of adjustment, business cycles and investment behaviour. In G. Dosi, C. Freeman, R. Nelson, G. Silverberg, L. Soete (eds) Technical Change and Economic Theory, pp. 38-66. London: Pinter.

Frenken, K. (ed.) (2007) Applied Evolutionary Economics and Economic Geography. Cheltenham UK: Edward Elgar.

Frenken, K., Van Oort, F. G., Verburg, T. (2007) Related variety, unrelated variety and regional economic growth, Regional Studies, in press.

Gabaix, X. and Ioannides, Y. (2004) The evolution of city size distributions. In V. Henderson and J.-F. Thisse (eds) Handbook of Regional and Urban Economics, vol. 4, pp. 2341-2378. Amsterdam: North-Holland.

Gertler, M. S. (1995) 'Being there': proximity, organization, and culture in the development and adoption of advanced manufacturing technologies, Economic Geography, 71: 1-26.

Grabher, G. (1993) The weakness of strong ties: the lock-in of regional development in the Ruhr area. In G. Grabher (ed.) The Embedded Firm, pp. 255-277. London: Routledge. 
Hagerstrand, T. (1967) Innovation Diffusion as a Spatial Process. Chicago: University of Chicago Press.

Hall, P. G. and Preston, P. (1988) The Carrier Wave. New Information Technology and the Geography of Innovation 1846-2003. London: Unwin Hyman.

Hall, P. A. and Soskice, D. (2001) Varieties of Capitalism. The Institutional Foundations of Comparative Advantage. Oxford: Oxford University Press.

Hannan, M. T., Carroll, G. R., Dundon, E. A., Torres, J. C. (1995) Organizational evolution in a multinational context: entries of automobile manufacturers in Belgium, Britain, France, Germany, and Italy, American Sociological Review, 60: 509-528.

Hassink, R. (2005) How to unlock regional economies from path dependency? From learning region to learning cluster, European Planning Studies, 13: 521-535.

Hodgson, G. and Knudsen, T. (2006) The nature and units of social selection, Journal of Evolutionary Economics, 16: 477-489.

Hohenberg, P. M. and Lees, L. H. (1995) The Making of Urban Europe 1000-1994. Cambridge, MA: Harvard University Press.

Iammarino, S. and McCann, P. (2006) The structure and evolution of industrial clusters. Transactions, technology and knowledge spillovers, Research Policy, 35: 1018-1036.

Jacobs, J. (1969) The Economy of Cities. New York: Vintage Books.

Klepper, S. (2001) Employee startups in high tech industries, Industrial and Corporate Change, 10: 639-674.

Klepper, S. (2002a) The evolution of the U.S. automobile industry and Detroit as its capital. Paper presented at 9th Congress of the International Schumpeter Society, Gainesville, FL, March 27-30.

Klepper, S. (2002b) The capabilities of new firms and the evolution of the U.S. automobile industry, Industrial and Corporate Change, 11: 645-666.

Klepper, S. and Sleeper, S. D. (2005) Entry by spinoffs, Management Science, 51: 1291-1306.

Kogut, B. and Zander, U. (1993) Knowledge of the firm and the evolutionary theory of the multinational corporation, Journal of International Business Studies, 24: 625-646.

Krugman, P. (1996) The Self-Organizing Economy. Cambridge: Blackwell.

Maggioni, M. A. (2002) Clustering Dynamics and the Location of High-Tech-Firms. Heidelberg: Springer.

Maggioni, M. A. (2006) Mors tua, vita mea? The rise and fall of innovative industrial districts. In M. Feldman and P. Braunerhjelm (eds) Cluster Genesis: Technology-based Industrial Development, pp. 219-242. Oxford: Oxford University Press.

Maggioni, M. A. and Uberti, T. E. (2005) International networks of knowledge flows: an econometric analysis, Papers in Economics and Evolution. Jena: Max Planck.

Malerba, F. and Orsenigo, L. (1996) Schumpeterian patterns of innovation, Cambridge Journal of Economics, 19: 47-65.

Martin, R. (1999) The new 'geographical turn' in economics: some critical reflections, Cambridge Journal of Economics, 23: 65-91.

Martin, R. and Sunley, P. (2006) Path dependence and regional economic evolution, Journal of Economic Geography, 6: 395-437.

Maskell, P. (2001) The firm in economic geography, Economic Geography, 77: 329-344.

Maskell, P. and Malmberg, A. (2007) Myopia, knowledge development and cluster evolution, Journal of Economic Geography, 7: 603-618.

Montgomery, C. A. (1994) Corporate diversification, Journal of Economic Perspectives, 8: $163-178$.

Nelson, R. R. and Winter, S. G. (1982) An Evolutionary Theory of Economic Change. Cambridge, MA/London: The Belknap Press.

Overman, H. and Ioaniddes, Y. (2001) The cross-sectional evolution of the U.S. city size distribution, Journal of Urban Economics, 45: 184-208.

Pasinetti, L. L. (1993) Structural Economic Dynamics. Cambridge: Cambridge University Press.

Penrose, E. (1959) The Theory of the Growth of the Firm. New York: Wiley.

Pumain, D. (2006) Alternative explanations of hierarchical differentiation in urban systems. In D. Pumain (ed.) Hierarchy in Natural and Social Sciences, pp. 169-222. Dordrecht: Springer. 
Pumain, D. and Moriconi-Ebrard, F. (1997) City size distributions and metropolisation, Geojournal, 43: 307-314.

Pumain, D., Paulus, F., Vacchiani-Marcuzzo, C., Lobo, J. (2006) An evolutionary theory for urban scaling laws. Mimeo.

Rigby, D. L. and Essletzbichler, J. (1997) Evolution, process variety, and regional trajectories of technological change in US manufacturing, Economic Geography, 73: 269-284.

Robson, B. T., (1973) Urban Growth: An Approach. London: Methuen.

Romer, P. (1990) Endogenous technological change, Journal of Political Economy, 98: S71-S102.

Saviotti, P. P. and Pyka, A. (2004) Economic development by the creation of new sectors, Journal of Evolutionary Economics, 14: 1-35.

Schumpeter, J. A., (1942) Capitalism, Socialism and Democracy. New York: Harper \& Row.

Simon, H. A. (1955) On a class of skew distribution functions, Biometrika, 42: 425-440.

Stam, E. (2007) Why butterflies don't leave. Locational behavior of entrepreneurial firms, Economic Geography, 83: 27-50.

Storper, M. and Walker, R. (1989) The Capitalist Imperative. Territory, Technology and Industrial Growth. New York: Basil Blackwell.

Stuart, T. and Sorenson, O. (2003) The geography of opportunity: spatial heterogeneity in founding rates and the performance of biotechnology firms, Research Policy, 32: 229-253.

Sutton, J. (1997) Gibrat's legacy, Journal of Economic Literature, 35: 40-59.

Teece, D., Pisano, G., Shuen, A. (1997) Dynamic capabilities and strategic management, Strategic Management Journal, 18: 509-533.

Wezel, F. C. and Van Witteloostuijn, A. (2006) From scooters to choppers: product portfolio change and organizational failure. Evidence from the UK motorcycle industry 1895 to 1993, Long Range Planning, 39: 11-28.

Weitzman, M. (1998) Recombinant growth, Quarterly Journal of Economics, 113: 331-360.

Winter, S. G. and Szulanski, G. (2001) Replication as strategy, Organization Science, 12: 730-743.

Wrigley, N., Coe, N. M., Currah, A. D. (2005) Globalizing retail: conceptualizing the distribution-based TNC, Progress in Human Geography, 29: 437-457.

Van den Berg, L. (1987) Spatial Cycles. Hampshire: Aldershot.

van Wissen, L. (2004) A spatial interpretation of the density dependence model in industrial demography, Small Business Economics, 22: 253-264.

Zipf, G. (1949) Human Behavior and the Principle of Least Effort. Cambridge MA: Addison-Wesley. 